\title{
PENANAMAN MANGROVE UNTUK KONSERVASI PANTAI TANJUNG SENGKUANG
}

\section{PLANTING MANGROVE FOR CONSERVATION TANJUNG SENGKUANG BEACH}

\author{
Adam $^{1}$, Aulia Putri ${ }^{2}$ \\ ${ }^{1,2}$ Pendidikan Bahasa Inggris, Universitas Riau Kepulauan Riau, Indonesia \\ ladamedumy@gmail.com, ${ }^{2}$ auliaputri1983@yahoo.com
}

\begin{abstract}
Abstrak
Berdasarkan data Badan Pengendalian Dampak Lingkungan Kota Batam menyatakan wilayah Batam kehilangan sekitar 800 hektar hutan mangrove sepanjang tahun 2015. Hal ini senada dengan kondisi pohon mangrove di Kelurahan Tanjung Sengkuang yang kelihatan sudah mulai punah dan tidak terpelihara akibat perusahaan-perusahaan yang berada disekitar pantai Tanjung Sengkuang menebang hutan bakau semenamena ditambah warga yang mempunyai kapal-kapal menebang pohon mangrove untuk dijadikan lahan tempat bersandarnya kapal. Tujuan dari Pengabdian Kepada Masyarakat ini diantaranya, untuk menanamkan rasa peduli masyarakat terhadap lingkungan hidup khususnya pohon mangrove, disamping itu juga kegiatan ini bertujuan untuk memberikan pengetahuan dan membangkitkan motivasi masyarakat akan pentingnya pelestarian hutan bakau untuk keberlangsungan hidup habitat laut dan juga untuk kesehatan warga sekitar pantai. Adapun metode kegiatan yang diterapkan dalam kegiatan ini menggunakan metode, ceramah, diskusi, simulasi, dan penyuluhan. Sasaran dari kegiatan ini yaitu KSM Tanjung Sengkuang Bersih, Karang Taruna Tanjung Sengkuang, Anak-anak sekolah, dan masyarakat sekitar pantai. Dari hasil kegiatan tersebut, penanaman pohon mangrove berjalan dengan lancar sesuai dengan yang direncanakan, hal ini terlihat jumlah pohon mangrove yang 1.200 batang 1 bulan setelah selesai kegiatan terlihat tumbuh dengan baik. Disamping itu juga masyarakat terlihat sangat antusias dalam menjaga lingkungan setelah kegiatan selesai.
\end{abstract}

Kata Kunci : Konservasi pantai, Penanaman Mangrove, Tanjung Riau

\begin{abstract}
Based on the data from the Environmental Impact Management Agency of Batam, the Batam area lost about 800 hectares of mangrove forest throughout 2015. This is in line with the condition of mangrove trees in Tanjung Sengkuang which appear to have become extinct and not maintained due to companies located around Tanjung Sengkuang cutting down the mangrove arbitrarily and the residents who have ships cutting down mangrove trees to be used as land for ships to lean on. The aims of this programs are, to instill a sense of community care for the environment, especially mangrove, in addition to provide knowledge and generate community motivation for the importance of preserving mangrove forests for the survival of marine habitats and also for the health of coastal communities. The method used in this activity are, lectures, discussions, and counseling. The targets of this activity are KSM Tanjung Sengkuang Bersih, Youth Organization, students, and the community around the beach. The results of these programs, it was seen that the number of mangrove 1,200 stems 1 month after the completion of the activities seemed to grow well along the beach. Besides, the community looks very enthusiastic in protecting the environment after the activities finished.
\end{abstract}

Keywords: Beach Conservation, Mangrove Planting, Tanjung Riau Village 


\section{PENDAHULUAN}

Kecamatan Batu Ampar merupakan salah satu Kecamatan dari 12 ( dua belas) Kecamatan yang ada di Kota Batam. Kecamatan Batu Ampar terbentuk bersamaan dengan Pemekaran Kecamatan di Kota Batam berdasarkan Perda No.2 Tahun 2005 tentang Pemekaran, Perubahan dan Pembentukan Kecamatan Kelurahan di Kota Batam.

Wilayah Kecamatan Batu Ampar seperti halnya Kecamatan - Kecamatan di Propinsi Kepulauan Riau lainya, juga merupakan bagian dari paparan Continental Benua Asia, pulau - pulau yang tersebar di daerah ini merupakan sisa - sisa erosi atau penyusutan dari daratan pra tersier yang membentang dari Semenanjung Malaysia, Pulau Singapore di bagian utara sampai dengan pulau - pulau Moro dan Kundur serta Pulau Karimun di bagian selatan dengan jenis tanah latosol dengan warna kuning muda yang mengandung banyak bauksit muda dengan tingkat kesuburan tanah sedang.

Wilayah Kecamatan Batu Ampar terkonsentrasi dengan radius $7 \mathrm{Km}$, sedangkan penyebaran penduduk tidak begitu merata di masing - masing Kelurahan dimana Permukaan tanah di Kecamatan ini pada umumnya terdiri dari :

- Datar : 50 Persen

- Berbukit : 35 Persen

- Bergelombang : 15 Persen

Kelurahan Tanjung Sengkuang adalah kelurahan di kecamatan Batu Ampar, Kota Batam, Kepulauan Riau, Indonesia dengan luas wilayah $20.251 \mathrm{Km} 2$, dengan jumlah penduduk 30.369 jiwa. Keluarahan Tanjung Sengkuang merupakan kawasan padat penduduk yang rata-rata mata pencaharian nya adalah pekerja pabrik, dan nelayan. Kelurahan Tanjung Sengkuang RT 19 RW 01 berada dipinggir pantai, yang mana pantai ini belum terlestarikan secara optimal. Menurut Solehuddin (2011) Pantai merupakan bagian wilayah pesisir yang bersifat dinamis, artinya ruang pantai (bentuk dan lokasi) berubah dengan cepat sebagai respon terhadap proses alam dan aktivitas manusia. Untuk mencegah kerusakan pantai perlu setiap individu ikut melestarikan lingkungan pantai karena hal ini merupakan tanggungjawab kita semua. Tanggung jawab setiap manusia yang hidup, tinggal, bekerja di tempat di mana ia tinggal. Berdasarkan pandangan ini 
tanggungjawab untuk memelihara kesinambungan daya dukung lingkungan menjadi tanggungjawab semua orang .

Sesuai dengan Permen Ristekdikti No. 44 tahun 2015 bahwa salah satu bentuk wujud tri dharma PT adalah Pengabdian kepada masyarakat. Untuk mewujudkan itu, kami memandang perlu melakukan pengabdian untuk berpartisipasi dalam upaya penyelamatan lingkungan hidup dari abrasi, dan kerusakan kerusakan yang dibuat oleh manusia itu sendiri. Terjadinya abrasi ini merupakan proses terjadinya pengikisan daratan oleh gelombang sehingga menyebabkan hanyutnya substrat dan berkurangnya luas daratan. (Veranita dan Adjie: 2013). Abrasi adalah proses pengikisan pantai oleh tenaga gelombang laut dan arus laut yang bersifat merusak, biasa disebut juga erosi pantai (Ukkas, 2009). Selanjutnya Kurnia (2009) menyatakan sedimentasi atau akresi adalah proses perkembangan gisik, gosong atau bura ke arah laut melalui pengendapan sedimen yang dibawa oleh hanyutan litoral. Penyebab terjadinya abrasi pesisir pantai diantaranya yaitu gelombang air laut, pasang surut, arus permukaan bawah laut. Kerusakan-kerusakan ini akan terus berkelanjutan apabila manusia itu sendiri tidak mengetahui manfaat ekosistem dari lingkungan.

Berdasarkan pra-observasi yang kami lakukan pada bulan Juni 2018 di Kelurahan Tanjung Sengkuang RT 05 RW 01 Kecamatan Batu Ampar, dapat dilihat beberapa kerusakan- kerusakan pada beberapa sisi pantai. Kerusakan itu bukan hanya karena faktor alam (akibat abrasi dan pengikisan bibir pantai oleh ombak) tetapi juga karena terjadi penebangan hutan oleh warga untuk sekedar tempat kapal-kapal bersandar, dan juga kerusakan yang dibuat oleh pabrik-pabrik yang ada disekitar lokasi pantai untuk membuang limbah pabrik. Untuk itu sebelum semuanya berjalan terlalu jauh yang berdampak pada kerusakan pantai yang semakin hari semakin tidak terkendali, maka kami mencoba melakukan penyuluhan dan pelatihan sekaligus penanaman pohon mangrove di lokasi tersebut. Menurut Gunarto (2004) lokasi mangrove biasanya berada di daerah muara sungai atau estuarin sehingga merupakan daerah tujuan akhir dari partikel-partikel organik ataupun endapan lumpur yang terbawa dari daerah hulu akibat adanya erosi. Dengan demikian, daerah mangrove merupakan daerah yang subur, baik daratannya maupun perairannya, karena selalu terjadi transportasi nutrien akibat adanya pasang surut. Penanaman pohon mangrove dinilai sangat berfungsi bagi ekosistem laut, diantara fungsi 
lainnya yaitu; fungsi fisik, Fungsi biologis atau Ekologis, dan fungsi Ekonomis (Ahmad:2017). Kegiatan penanaman mangrove ini ditujukan kepada masyarakat setempat dengan melibatkan tokoh masyarakat, pemerintahan desa, pemuda Karang taruna, Pelajar, Dinas Lingkungan Hidup, dan Tokoh-tokoh KSM. Sedangkan penanaman pohon mangrove melibatkan beberapa anak muda dan masyarakat sekitar dan dibantu oleh beberapa mahasiswa dari Universitas Riau Kepulauan. Menurut Pratiwi (2017) Penghijauan sangat bermanfaat guna menanggulangi berbagai penurunan kualitas lingkungan dengan menggunakan penanaman pohon yang dapat berfungsi dalam biotis tata lingkungan.

\section{METODOLOGI}

Metode pelaksanaan kegiatan PKM Penanaman Mangrov Untuk Konservasi Pantai tanjung Sengkuang adalah memberikan makna terlebih dahulu kepada masyarakat betapa pentingnya pelestarian lingkungan; dan memberikan penyuluhan dan dikusi tentang manfaat dan cara penanaman mangrove. Adapun alur PKM ini digambarkan dalam diagram berikut berupa solusi yang ditawarkan untuk mengatasi permasalahan yang ada.

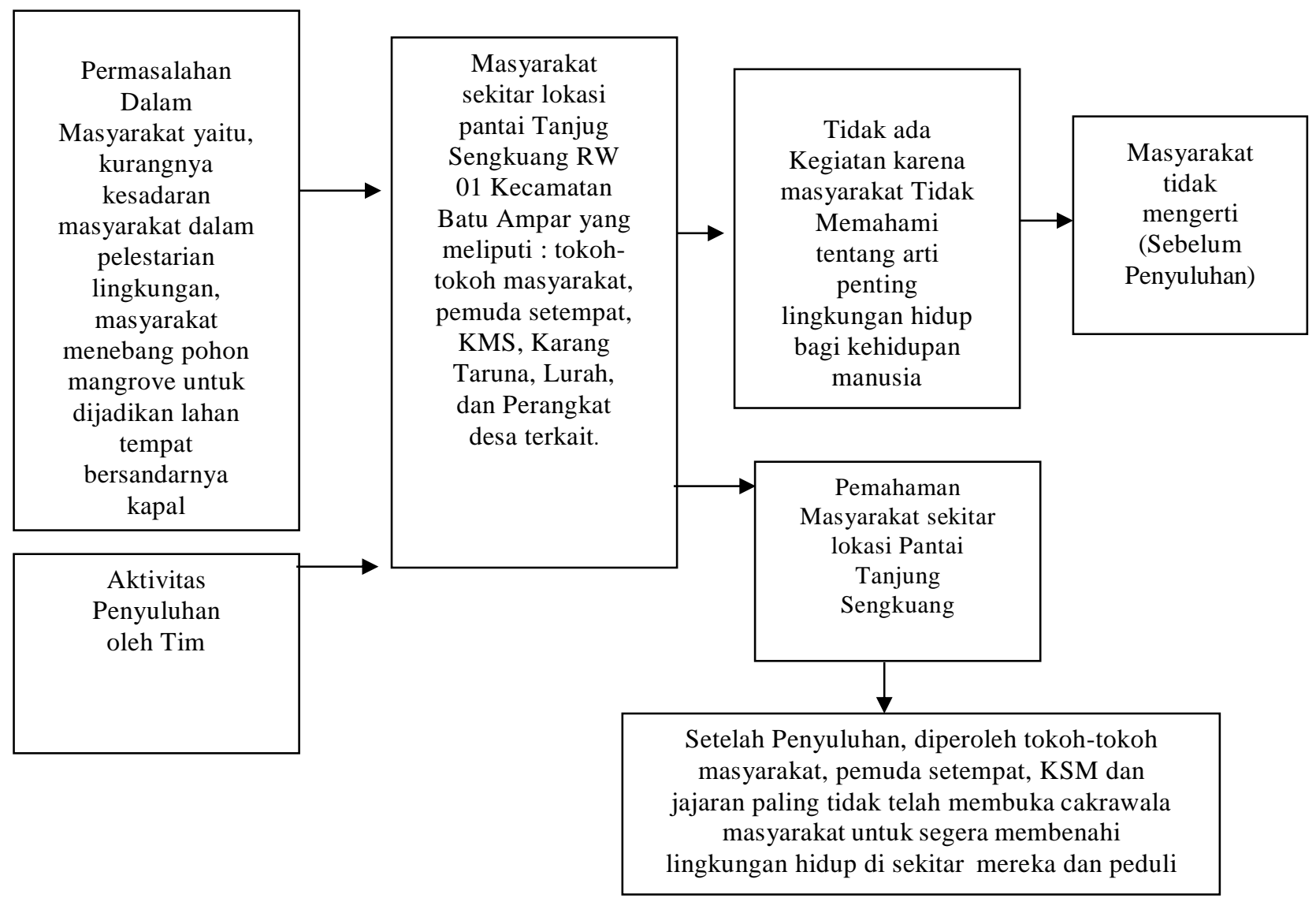




\section{Diagram 1. Alur dan Solusi PKM}

Adapun metode/tahapan kegiatan yang kami lakukan dalam kegiatan ini adalah sebagai berikut :

Survey lapangan, Menurut Mubyanto dan Suratno ( 1981 ) survey merupakan satu cara yang utama untuk mengumpulkan data primer bila data sekunder dianggap belum cukp lengkap utuk menjawab sesuatu pertanyaan. Pada tahapan ini tim melakukan survey ke Kelurahan Tanjung Sengkuang RT 05 RW 01. Dimana kegiatan survey ini adalah kegiatan awal yang kami lakukan guna untuk memperoleh data dan informasi faktual dari masyarakat Kelurahan Tanjung Sengkuang. Dalam kegiatan ini kami melihat lokasi pantai dan kerusakan-kerusakan yang dibuat nelayan, dan limbah industri, dan sekaligus menentukan titik lokasi penanaman mangrove. Dari hasil kegiatan survey ini tim membuat rencana dan agenda untuk menyusun program selanjutnya.



Figure 1.Foto kegiatan Survey lokasi penenaman manmgrove

Penyuluhan, pada tahapan ini tim mengumpulkan masyarakat untuk menyamakan visi dan misi kegiatan ini terlebih dahulu, kemudian tim mengundang pemateri dari dinas lingkungan hidup kota Batam untuk memberikan penjelasan penjelasan tentang manfaat dari ekosistem mangrove untuk kehidupan masyarakat.




Figure 2. Foto Penyuluhan Penanaman mangrove

Ceramah/presentasi, metode ceramah ini merupakan proses pemberian informasi kepada masyarakat yang guna untuk memahami hakikat dan manfaat pohon mangrove bagi lingkungan. Pada tahapan ini tim menyampaikan langkah-langkah kerja dalam kegiatan penanaman mangrove. Dalam kegiatan ini dihadiri ketua dan anggota KSM Tanjung Sengkuang dan Ibu-ibu PKK RT 05 RW 01.
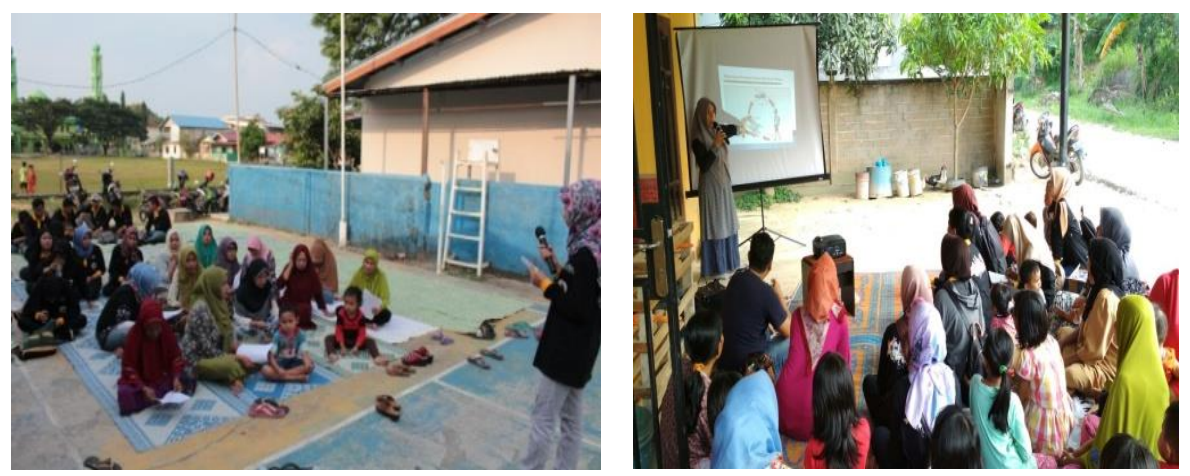

Figure 3. Foto Ceramah dan persentasi penanaman mangrove

Persiapan, dalam kegiatan ini tim dan beberapa orang mahasiswa mempersipkan dan mimilah bibit mangrove yang sudah bisa ditanam di Rumah Bakau Indonesia (RBI). Bibit mangrove yang sudah bisa ditanam biasanya ketika sudah berumur 6 bulan dan telah memiliki 4 buah daun.

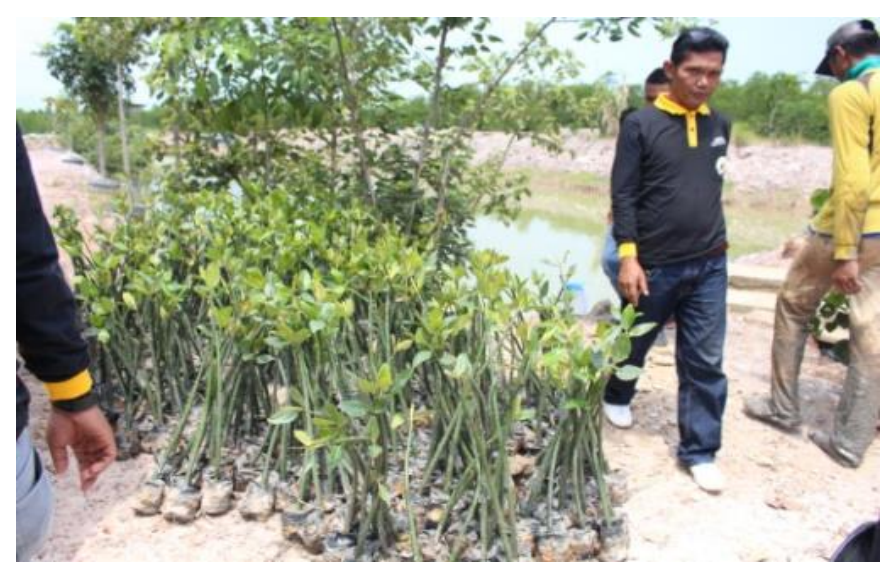

Figure 4. Foto Persiapan Bibit Mangrove

Penanaman, pada acara puncak penanaman mangrove ini berlangsung pada hari 
Minggu tanggal 19 Agustus 2018. Kegiatan ini dihadiri dari berbagai pihak seperti, Universitas Riau Kepulauan, Dinas Lingkungan Hidup Kota Batam, Ketua Karang Taruna Kota Batam, Lanal Batam, RBI Kota Batam, anak-anak pramuka, dan seluruh masyarakat Tanjung Sengkuang. Pada kegiatan ini masyarakat yang terlibat terlihat sangat antusias dalam mengikuti kegiatan penanaman pohon mangrove. Dan kegiatan ini berjalan dengan lancar sesuai yang diharpkan.

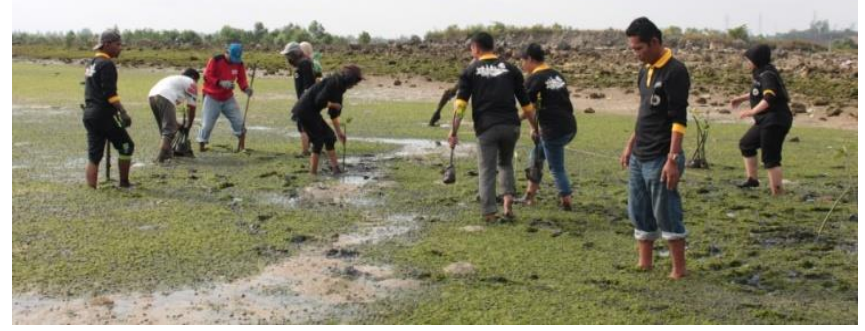

Figure 5. Foto Kegiatan Penanaman Mangrove

\section{HASIL DAN PEMBAHASAN}

Kegiatan ini dilaksanakan pada hari Sabtu dan Minggu, tanggal 21 Juli sampai 19 Agustus 2018 di Kelurahan Tanjung Sengkuang RT 05 RW 01 Kecamatan Batu Ampar Batam Provinsi Kepulauan Riau yang dihadiri oleh 30 orang pada saat penyuluhan sedangkan pada saat penanaman pohon mangrove jumlah masyarakat yang hadir sebanyak 25 orang. Pohon Mangrove ini ditanam dibibir pantai dengan luas area 3 Ha yang berjarak sekitar $100 \mathrm{~m}$ dari rumah-rumah warga. Total pohon mangrove yang ditanam berjumlah 1.200 batang.

Peserta kegiatan ini terdiri dari tokoh-tokoh masyarakat, pemuda setempat, KSM, Anggota Karang Taruna, Lurah setempat, ibu-ibu PKK, perangkat desa terkait. Dan juga turut Lanal Batam, dan dinas lingkungan hidup kota Batam. .

Kegiatan pengabdian ini diawali pada tahap persiapan pada awal bulan Juni 2018 yakni diawali dari penjajakan dan survey di lapangan. Pada bulan Juli itu diperoleh informasi bahwa di lokasi pantai Tanjung Sengkuang yang terguras oleh kapal-kapal nelayan dan juga akibat limbah industri yang dibuang ke pantai. .

Pada tahap berikutnya tim sosialisasi ini menyusun proposal dengan mengumpulkan beberapa reverensi terkait tentang pelestarian lingkungan hidup, fungsi hutan serta dampaknya 
bagi kehidupan manusia. Dan pada tahap ini tim juga mengadakan diskusi dengan mengundang kepala Kehutanan dan Dinas Lingkungan Hidup kota Batam untuk memberikan penyuluhan terkait pentingnya tanaman mangrove untuk mencegah abrasi di pantai, dan juga untuk mengurangi emisi $\mathrm{CO} 2$ yang banyak berasal dari industri sekitar pantai. Setelah proposal tersusun dengan baik tim mengajukan proposal tersebut untuk mendapat persetujuan dari RW setempat, Lanal batam, dan Lurah Tanjung Sengkuang untuk selanjutnya diteruskan ke Rumah Bakau Indonesia (RBI).

Pelaksanaan kegiatan tersebut pada minggu-minggu berikutnya yaitu pada pertengahan bulan Juli 2018 dilakukan penjajakan tempat kegiatan penanaman pohon dan akhirnya disetujui pelaksanaan itu dilaksanakan di pinggir pantai Kelurahan Tanjung Sengkuang RT 05 RW 01 Kecamatan Batu Ampar Batam Provinsi Kepulauan Riau. Secara simultan kegiatan selanjutnya adalah menyampaikan undangan kepada para peserta terutama kepada peserta warga yang berdomisili disekitar bibir pantai untuk ikut berpartisipasi dalam penanaman pohon bakau.

Selanjutnya, kegiatan penyuluhan ini akhirnya dapat dilaksanakan pada pukul 10.00 Wib dan ditutup hingga pukul 16.00 Wib. Dalam kegiatan penyuluhan tersebut disampaikan ceramah interaktif yang intinya adalah mensosialisasikan peraturan lingkungan hidup, pentingnya pohon mangrove disamping sebagai menjaga habitat laut juga bisa menambah income bagi warga seperti pengolahan buahnya menjadi cemilan, dan aneka makanan lainnya. Dalam kegiatan tersebut dapat dipahami bahwa masyarakat sangat antusias untuk segera melakukan penanaman pohon untuk konservasi Pantai di Kelurahan Tanjung Sengkuang RT 05 RW 01 Kecamatan Batu Ampar Batam Provinsi Kepulauan Riau.

\section{KESIMPULAN}

Kesimpulan yang diperoleh dari kegiatan "Penanaman Mangrove Untuk Konservasi Pantai di Kelurahan Tanjung Sengkuang Kecamatan Batu Ampar Kota Batam" adalah, Masyarakat di RT 05 RW 01 Kelurahan Tanjung Sengkuang Kecamatan Batu Ampar menjadi peduli dan mengetahui tentang arti pentingnya lingkungan hidup bagi kehidupan manusia. Dan juga partisipasi masyarakat dalam pemeliharaan lingkungan pesisir pantai tidak terlepas peran serta dari semua komponen yang ada disekitar, seperti perusahaan-perusahaan, nelayan, dan pemerinatah terkait. Keefektivitasan penegakan hukum lingkungan dapat dilakukan apabila masyarakat disekitar pantai tersebut ikut 
dilibatkan secara aktif dan diberikan pencerahan lebih bahwa hutan bakau yang ada disekitar mereka pada dasarnya adalah untuk kesejahteraan dan kegunaan untuk mereka sendiri.

\section{REFERENSI}

Ahmad, D.N. 2017. Penyuluhan dan Pelatihan Upaya Pencegahan Abrasi Pantai Pada Masyarakat Muara Gembong Bekasi. Jurnal Panrita Abdi, 1(2): 90-96.

Badan Pusat Statistik Kepulauan Riau. 2017. Jumlah penduduk Kota Batam

Damaywanti Kurnia. Dampak Abrasi Pantai terhadap Lingkungan Sosial (Studi Kasus di Desa Bedono, Sayung Demak). Prosiding Seminar Nasional Pengelolaan Sumberdaya Alam dan Lingkungan. 2013. ISBN 978-602-17001-1-2: 363-367.

Gunarto. 2004. Konservasi Mangrove Sebagai Pendukung Sumber Hayati Perikanan Pantai, Jurnal Litbang Pertanian, 23(1) :15-21

Mubyanto dan Suratno. 1981. Teori Komunikasi, Jakarta: Univ. Terbuka

Pratiwi, Ayu Diah: 2017. Pemberdayaan Masyarakat RW 12 Dalam Kegiatan Penghijauan Lingkungan di Kavling Mandiri Kelurahan Sei Pelunggut. Jurnal Minda Baharu, 1(1): 25-32

Peraturan Perda No.2 Tahun 2005 tentang Pemekaran, Perubahan dan Pembentukan Kecamatan Kelurahan di Kota Batam.

Permenristek dikti No. 44 Tahun 2015

Solehuddin. 2011. Karakteristik Pantai Dan Proses Abrasi Di Pesisir Padang Pariaman, Sumatera Barat. Jurnal Globë, 13(2): 112 - 120.

Veranita, U. H. dan Adjie, P. 2013. Identifikasi Kawasan Rentan Terhadap Abrasi di Pesisir Kabupaten Tuban. Jurnal Teknik Pomits Vol. 2, No. 2, (2013) ISSN: 23373539 (2301-9271 Print).

Ukkas, M. 2009. Studi Abrasi dan Sedimentasi di Perairan Bua-Passimarannu Kecamatan Sinjai Timur Kabupaten Sinjai. Akuatik-Jurnal Sumberdaya Perairan, 3 (1): 20-29 